\title{
REMOVAL VERBS AND LOCATIVE ALTERNATIONS IN SPANISH
}

\author{
José Luis Cifuentes Honrubia \\ Universidad de Alicante \\ Cifu@ua.es
}

\begin{abstract}
Resumen
Este trabajo analiza los verbos de remoción dentro del conjunto de las alternancias locales consideradas en español. Demostraremos que, en español, la diferenciación entre verbos de manera y verbos de resultado no se correlaciona con verbos con alternancias y verbos $\sin$ alternancias. Analizaremos diversos subtipos de verbos de remoción y sus pautas diferenciadoras.

PALABRAS CLAVE: verbos de remoción, alternancias locales, estructura argumental.
\end{abstract}

\begin{abstract}
This paper analyzes the removal verbs within the set of the locative alternations concerning Spanish. It is shown that the difference in Spanish between manner verbs and result verbs does not correlate with verbs triggering alternations and verbs which do not trigger them. Furthermore several subtypes of removal verbs and their defining guidelines are analyzed.

KEYWORDS: removal verbs, locative alternations, argument structure.
\end{abstract}

\section{Alternations ${ }^{1}$}

Verb alternations are syntactic structures that interrelate using a significant opposition. That is to say, different associations or correlations that can occur between the semantic functions of the arguments a verb requires and the syntactic functions they carry out. Therefore, it refers mainly to argument structure alternations, derived from the observation that a given verb can be associated with a different number of arguments depending on its use, as well as allowing changes in the grammatical relations between arguments. For example, constructions like cargó leña en el carro (he loaded wood on to the cart) and cargó el carro con leña (he loaded the cart with wood) show a specific alternation in argument structure. They are an example of the possibility of a double construction found in some verbs that are able to form two different syntactic structures with the same objects. Furthermore, some researchers have used alternations in argument structure as a criteria to distinguish verb classes: there are certain syntactic and/or semantic features which are shared by all the verbs that follow a particular alternation.

Therefore, alternations in the syntactic organization of argument structure indicate the systematic relation between semantics and syntax. Furthermore, these alternations are linked to (lexical semantic) verb classes: verbs that share the same meaning components belong to the same semantic type and have the same syntactic behaviour (or alternations). These alternations represent the different syntactic possibilities a verb has of expressing its arguments without altering the basic meaning components and therefore,

1 This work has been made possible partly thanks to research project HUM2006-09429/FILO. 
the semantic class the verb belongs to. Levin's work (1993) is the first great verb classification and refers, of course, to English. According to Levin (1993: 14), verbs which share alternations should belong to a coherent semantic class. She has identified up to 50 alternations that compose eight basic schemas: transitivity alternations, alternations involving arguments within the verb phrase (VP), oblique subject alternations, reflexive diathesis alternations, passive alternations, alternations involving post-verbal subjects, "other" constructions (cognate object constructions, resultative constructions, etc.), and verbs requiring special diathesis. These alternations have been adapted into Spanish in roughly 60 classes (Cifuentes, 2006b).

\section{Locative alternations}

The so-called "locative alternation" occurs in certain three-argument verbs that have a figure, locatum or theme argument (the substance or entity that undergoes a change in its location), and a base argument or location. In each variant one argument becomes the direct object and the other becomes the oblique object, swapping positions in each of the alternating variants.

$$
\begin{array}{lcccc}
\text { Cargó } & \text { leña } & \text { en el carro/ Cargó } & \text { el carro } & \text { con leña } \\
\text { (He loaded } & \text { wood } & \text { on to the cart)/(He loaded } & \text { the cart } & \text { with wood) } \\
& \text { Direct Object } & \text { Prepositional Object } & \text { Direct Object Prepositional Object } \\
\text { Locatum } & \text { Location } & \text { Location } & \text { Locatum }
\end{array}
$$

Levin, in her paradigmatic work on verb classes (1993), provides the first classification of locative alternations based on 5 subclasses:

a. Rociar/cargar (spray/load) class. This form of locative alternation includes transitive verbs that are linked to positioning or covering something. Like all forms of locative alternation, it is supposed to show the holistic/partitive ${ }^{2}$ effect. Examples: spray, load, brush, cram, pack, pile, jam, scatter, splatter, stuff.

Jack roció pintura sobre el muro (Jack sprayed paint on the wall).

Jack roció el muro con pintura (Jack sprayed the wall with paint).

2 Anderson (1971), after previous works by Hall, Fraser and Fillmore, uses the terms holistic interpretation and partitive interpretation in order to represent the significant difference between locative alternations, depending on whether the whole of something is affected or just a part of it is.

Let us consider the following alternation example:

a) Antonio cargó el carro con leña (Antonio loaded the cart with wood).

b) Antonio cargó leña en el carro (Antonio loaded wood on to the cart).

In the first example, (a), the cart is considered to be completely loaded. The location is performed by the Noun Phrase (el carro-the cart), so the holism will normally be referred to represent the location being covered or occupied. In example (b), where location is shown by the Prepositional Phrase (en el carro-on to the cart), there is no such implication, hence its denomination as partitive interpretation. 
b. Vaciar (clear) class. This form of locative alternation is supposed to occur with verbs that, in principle, are the opposite to verbs from the previous group. They too show the holistic/partitive effect. Examples: clear, clean, drain, empty.

Henry limpió los platos de la mesa (Henry cleared dishes from the table)

Henry limpió la mesa de platos (Henry cleared the table of dishes)

c. Cepillar (wipe) class. This form of locative alternation occurs, as does the previous type, with opposite verbs to the rociar/cargar (spray/load) class. However, these verbs differ from the vaciar (clear) class in that they do not allow the locatum argument to be expressed when the location argument works as a direct object. This means that in English these verbs cannot adopt the prepositional structure they can in Spanish. Examples: wipe, wear, bail, buff, dab.

Helen limpió [con un trapo]las huellas del cristal (Helen wiped the fingerprints off the wall) Helen limpió [con un trapo] el cristal (de huellas) (Helen wiped the wall (*of fingerprints))

d. Pulular (swarm) class. This form of locative alternation occurs with transitive verbs and, just like the previous class, they do not have a clear Spanish equivalent. These verbs are parallel to the rociar/cargar (spray/load) alternation as long as the role played by the intransitive subject is considered the same as the role played by the object in the rociar/cargar (spray/load) class. They are also frequently associated with the holistic/partitive effect ${ }^{3}$. Examples: swarm, abound, bustle.

If we use a verb that does not exactly show a container/content relation, but that refers to surfaces, such as rociar (spray), the effect is similar:

a) Rocio la pared con pintura (he sprayed the wall with paint).

b) Rocio pintura en la pared (he sprayed paint on the wall).

In example a), it is understood that the pared (wall) was completely covered with paint marks. However, in example b), the holistic effect disappears and there is no implication whatsoever as to the entirety of the pared.

Therefore, when location comes about not through the prepositional object, but through the direct object, it is said that the location is affected as a whole by the action the verb describes (la pared, el carro-the wall, the cart) thanks to the element introduced by a preposition (con pintura, con leña-with paint, with wood). This effect on the object as a whole is not necessarily implied in constructions with local prepositional phrases (en la pared, en el carro-on the wall, on to the cart), where the location assumes the role of direct object (pintura, leña-paint, wood).

3 Di Tullio (2002: 139) separates three verb subtypes, mainly inaccusative, stative and perfective verbs, that suggest a limit and can be divided in three semantic groups:

a) Those which indicate an agglomeration of elements: abundar, pulular, hervir, bullir, hormiguear (abound, swarm, seethe, bustle):

La orilla izquierda del Sena hormiguea de samurais desorientados (the left bank of the river Seine is bustling with disorientated samurai)

Samurais desorientados hormiguean en la orilla izquierda del Sena/disorientated samurai are bustling on the left bank of the river Seine.

b) Verbs that indicate shedding light: brillar, resplandecer, refulgir, rutilar (shine, gleam, glow, sparkle): El cartel refulgia de luces (the sign shone with lights). Las luces refulgian en el cartel (the lights shone on the sign).

c) Verbs that indicate sounds: retumbar (resound). La cavern retumbaba con nuestros pasos (the cavern resounded with our steps). Nuestros pasos retumbaban en la cavern (our steps resounded in the cavern).

However, although the examples in a) clearly work, I think I am not mistaken in suggesting they seem strange. 
Las abejas pululaban en el jardin (Bees are swarming in the garden)

?El jardin pululaba de abejas (The garden is swarming with bees)

e. Vaciarse (clear2) class. This form of locative alternation is not possible in Spanish either. It is understood as the intransitive counterpart to the transitive use of the clear class. The intransitive form of this alternation does not have an agent and shows the holistic/partitive effect just like the previous four. Examples: clear, drain, empty.

?Los nubarrones se despejaron del cielo (Clouds cleared from the sky)

El cielo se despejó de nubarrones (The sky cleared (of clouds))

Despite this classification in five subtypes, Levin recognizes locative alternations in other verb groups, such as creation and transformation or image impression. Perhaps the reason not to include them in the first place is that they do not show the holistic/partitive effect. However, in spite of the importance of Levin's classification, the truth is that she herself later simplifies her classification even more. In later works (Rappaport and Levin 2003; Levin, 2003; 2006), when dealing with object alternations (intransitive alternations are later excluded), she distinguishes only two locative alternations:

a. A positioning subtype, including the rociar/cargar (spray/load) type

b. A removal subtype, including the vaciar (clear) and vaciarse (clear2) types.

Perhaps the benefit of this work lies not in the mere simplification of five subtypes to two, but in the treatment as a whole of all the object alternations because they are all argument alternations which affect three-argument verbs and keep the same subject, although their other two arguments can exchange roles to become either the object or the prepositional phrase. These two authors differentiate six types of object alternations ${ }^{4}$. The following locative alternations are added to the two previous ones:

c. Product/material alternation:

Martha tallo un juguete de una pieza de Madera (Martha carved a toy out of the piece of wood).

* Martha talló la pieza de Madera en un juguete (Martha carved the piece of wood into a toy).

d. Image impression alternation:

Taylor bordó flores en la chaqueta (Taylor embroidered peonies on the jacket).

Taylor bordó la chaqueta con flores (Taylor embroidered the jacket with peonies).

e. With/against alternation:

Sam golpeó la valla con un bate (Sam hit the fence with a stick).

Sam golpeó un bate contra la valla (Sam hit a stick against the fence).

4 Although Levin (2006) does not take the last subtype into account. 
f. Body-part possessor ascension alternation:

Terry palmeó mi espalda (Terry slapped my back).

Terry me palmeó en la espalda (Terry slapped me on the back).

The moment the oblique object that is able to alternate becomes a locative clause (introduced by a location preposition), there may be reason to increase the number of locative alternation types, especially in Spanish. Thus, the image impression alternation, for example, could well be considered a subtype of locative alternation, because it alternates a locative preposition phrase with a direct object construction.

It should come as no surprise, then, that in English so many considerations have derived from two main locative alternation groups; transitive (such as cargar (load)) and intransitive (such as pulular (swarm)), possibly differentiating removal verbs as another subtype.

Laffut's work (2006) is very enlightening in this field. In her investigation on threeparticipant constructions in English she also focuses on locative constructions, image impression constructions and material/product constructions. Basically, constructions affected by alternations have one agentive entity, and two non-agentive entities which can switch from being prepositional phrases to noun phrases. In general terms, they tend to be defined as follows: locative alternation is related to applying substances to surfaces or transferring things into containers. Image impression alternation is believed to be strongly linked to the previous type, with which it even shares certain verbs, but it is related to a different kind of "application", that of printing an image onto something. The material/product alternation appears to be completely different semantically since it does not involve transferring a substance or occupying a container, but refers to creating something using a material.

\section{Manner and result}

Beavers (2006: 172) explained that the durative aspect, seemingly so common in locative alternation constructions ${ }^{5}$, is strongly linked to having a manner component in the verb meaning. This is so because manner components normally include a series of steps that constitute manner, where each step is a sub-part in the complex event. In much the same way, the notion of result has sometimes been compared with telicity because telicity normally implies a result state (Pustejovsky, 1991), and some result verbs must be telic. Nevertheless, Rappaport and Levin (2008) provide various reasons to believe that the two notions should not be considered equivalent.

This is a very important aspect because, according to Rappaport and Levin, the difference between verbs that alternate and verbs that do not lies in the manner component. This idea, first suggested by Rappaport and Levin (1988: 27), is later picked up by Pinker (1989: 128 ), who states that in order for the verb to alternate, it must express a particular manner of cause or motion. Talmy (1985) states that when a verb expresses motion, it can also express manner of motion or change. According to Talmy, the basic motion event schema includes figure, ground, path and motion. Along with these internal components, the event

5 The analysis of the supposed holistic/partitive effect in locative alternations has moved the subject in discussion towards the idea that locative alternations are correlated to a change in aspect. 
can include manner or cause. The figure is the object that moves or is situated with respect to other objects (the ground - or base--). The path is the direction followed or the place the figure object is at in relation to the ground object. The motion refers to the presence of actual movement or location in the event. The manner refers to an action or state that is ancillary to the one expressed in the main action or state. Most motion verbs in Indo-European languages regularly incorporate manner in the motion, although there are languages which use satellites to express manner. That is to say, in a language group's typical motion events, the verb can express both the motion and its manner or cause.

Incorporating the manner component (or type of action) conflated with the verb is one of the possibilities this conceptual element has of being represented syntactically. It can also be represented linguistically in the shape of a satellite or a separate lexical element such as a gerund:

Corrió hasta el supermercado (he ran to the supermarket) /Vino corriendo hasta el supermercado (he came running to the supermarket) ${ }^{6}$.

Therefore, according to Rappaport and Levin, the difference between verbs that alternate and verbs that do not, such as poner (put), is the manner component. This manner component is even shown in the representation of the lexical conceptual structure:

a. [X cause [Y to come to be in $\mathrm{Z}]$ /MANNER] - en (in) alternation.

b. [[X cause $[Z$ to be in a STATE]] BY MEANS OF [X cause [Y to come to be in $Z] /$ MANNER] - con (with) alternation.

Verbs such as rociar (spray) or cargar (load) allow locative alternation precisely because they express the manner component, whereas verb classes that do not alternate only express a change in location. Poner (put), for example, does not specify how the change in position occurs, whereas rociar (spray) does: puso la pintura sobre la pared (he put the paint on the wall) merely shows that the paint has been moved, whereas rocio pintura sobre la pared (he sprayed paint on the wall) also specifies that this change in position has occurred through an even distribution of small drops of paint over the surface of the wall. Therefore, the con (with) variant and locative variants are not possible merely because of argument alternation in verbs with one meaning; on the contrary, Levin and Rappaport suggest that in both cases a difference in meaning is implied, and that verbs that belong to a different class depend on their use in a particular context. In order to allow this alternation, these verbs must have a manner component.

There are, therefore, three verb groups:

a. Verbs that imply a change in location in a particular manner (rociar-spray), and can alternate.

b. Verbs that merely imply a change in location, not specifying manner (poner-put), and can not alternate.

c. Verbs that do not imply a change in location, but a result state brought about by a change in position but which is not profiled (llenar-fill).

6 Vid. Cifuentes Honrubia 1999 
This third group is characterised, in addition to other features, by allowing the con (with) construction: llenó el vaso con agua (he filled the glass with water), but not allowing alternation: *Llené agua en el vaso (I filled water into the glass). These are non-locative verbs which specify that an element (agua-water) completely occupies an object/location. However, the possibility for the figure to change position is not profiled, although it is clear that for the result of llenar (fill) to come about, a change of position must occur, but this change of location is not expressed. It is the case of many other verbs that have nothing to do with locative alternations, such as contener (contain): la caja contenia muchos libros (the box contained a lot of books). This sentence implies possession, though by an inanimate element. In order for those objects to be inside the box, since they did not come out of thin air, someone must have placed them there, but this situation is not profiled in the construction, although it can be assumed extralinguistically. The same happens with llenar (fill) and other verbs: they do not linguistically imply a change of position, although one may guess that a change is necessary in order to explain the scene they set. Therefore, this type of verb, those which allow a con (with) construction but not locative alternation, will not be studied. In order for them to be considered in locative alternation, first they must have a locative configuration since, according to Rappaport and Levin, it is the manner component which allows these locative verbs to use the alternating con (with) construction.

According to Rappaport and Levin (2003), verbs which include a manner component in their meaning have more argument realisation options than verbs which include a result component, such as llenar (fill). This is due to the fact that manner verbs are inherently linked to simple event structures, which can be enhanced under appropriate circumstances. Verbs with simple event structures allow object alternation (the group of locative alternations we have described), because the rules that link event structure to syntax only require the subject to be realised; object alternations can occur when there are two "non-actor" arguments associated with a simple event verb and two different ways of expressing them both at the same time. These authors argue that, rather than the aspectual notion of "activity" (which also characterizes many manner verbs), it is the simplicity of the event which is the key factor, given that stative verbs, which are simple event verbs, may show object alternations such as possession alternations:

\footnotetext{
Admiro en Cristina su bondad e inocencia ladmiro la bondad e inocencia de Cristina / admiro Cristina porlen su bondad e inocencia.

("I admire about Cristina her kindness and innocence / I admire Cristina's kindness and innocence / I admire Cristina for her kindness and innocence)
}

In order to show these alternations, however, a stative verb must have the correct number of arguments and it is the prepositions that must allow the non-subject argument to be expressed as an oblique object.

Variants of alternations tend to denote complex events which consist of a cause subevent (that contains the verb root) and a result sub-event where the result is a conventional outcome of the cause sub-event (Levin, 2006):

a) Complex event structure:

[[ X ACTIVITY <manner>] CAUSE [BECOME [Y <result state $>]]]$ 
b) Simple event structure:

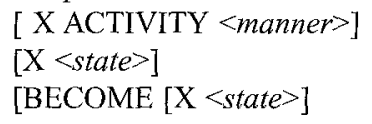

There are various types of result sub-events: addition (rociar-spray), ablation (limpiarwipe), creation (construir-build), etc. Although verbs with alternations have simple event structures, their alternations have complex event structures that are built on simple event structures and characterised by a particular type of result. Therefore, only verbs with roots describing manner can be used to obtain various types of result with multiple alternations. If a verb describes a manner used only to obtain a very specific result, such as aspirar (vactum), it will not allow for a very wide array of alternations (aspiró el polvo de la alfombra -he vacuumed the dust off the carpet-/*aspiró la alfombra de/con polvo -he vacuumed the carpet of/with dust-); in the same way, if a verb describes a manner which is not used to obtain a particular result, such as leer (read), it will show no alternations (Levin, 2003).

This is based on the idea that the lexical semantic representation of a verb determines the morphosyntactic realisation of its arguments. The differences between the various derivational models are determined by taking into account the structural meaning component of the verb, whether it is defined semantically or syntactically. It is the structural part of meaning that is used to determine semantic verb classes that are relevant for grammar, as opposed to the idiosyncratic part of verb meaning (verb root), made up of the aspects of meaning used to distinguish among verbs belonging to the same group and which is therefore irrelevant from a grammatical point of view. This structural part, in Rappaport and Levin's derivational model, is a lexical semantic schema, known as an event structure, which a verb shares with other verbs of the same group and which is one of two verb meaning components. The other part is an idiosyncratic meaning, or root, and distinguishes a verb from others belonging to the same class?

Thus, what are known as locative alternations require two "non-actor" arguments (locatum and location) associated with a simple event verb structure and two different ways of realising them at the same time. The roots are inherently associated with two or three participants and the non-verb predicates, which means a simple event verb structure must be raised to a complex event structure. For example (Levin, 2006), limpiar (wipe) describes a process, its root is basically associated with an actor and a surface. The event structure of limpiar (wipe) does not entail any result in particular even though wiping is a way of removing stuff from a surface. The event structure of limpiar (wipe) can be enhanced by adding a predicate to produce a complex removing event with an added predicate that allows for the argument of "stuff", with the object location appearing in a newly introduced result clause.

a) Kelly limpió la mesa (Kelly wiped the table). [X ACTIVITY <limpiar (wipe) > Y]

b) Kelly limpió las migajas de la mesa (Kelly wiped the crumbs off the table). [[X ACTIVITY <limpiar (wipe)> Y] CAUSE [BECOME [z NOT IN THE <lugar (location)>]]]

7 The equivalence with the constructional proposal, especially Iwata's (2005a, 2005b), is obvious. 
Having a simple event structure is necessary for alternation, but is not enough. Complex event structures consist of two parts; a causing sub-event, and a result sub-event. Result subevents can be of different types and make for different types of complex events. The variants in argument alternation can be distinguished by the type of result associated, such as being located or existing. When verbs with manner roots are based on complex event structures, the type of result must be one that can be obtained naturally according to the type of manner. Thus, only verbs whose roots describe manners that may obtain various types of result are able to show multiple argument realization. On the other hand, a verb whose root describes a manner used to obtain a very specific result does not allow alternations. The verb aspirar (vacuum), which is linked to the instrument used to remove stuff from a surface, is only found in the removing form of the locative alternation (Levin y Rappaport, 2005:233).

Aspiró la alfombra (he vacuumed the carpet) / aspiró las migajas de la alfombra (he vacuumed the crumbs from the carpet) / *aspiro la alfombra con migajas (he vacuumed the carpet with crumbs).

Rappaport and Levin (2008) state that, often, manner and result are in complementary distribution: a given verb tends to be classified as a manner verb or as a result verb, but does not have both characteristics. Rappaport and Levin define manner verbs as those whose meaning specifies the manner in which an action is carried out, whereas result verbs specify what occurs to bring about a result state. Fregar (scrub) and correr (run) are examples of manner verbs, and vaciar (empty) and llenar (fill) are examples of result verbs. However, conscious of how difficult it is to differentiate, they explain that in order to better understand the definition, we must assume a distinction between what a verb codifies lexically as part of its meaning and what can de inferred from a particular use of the verb in context. For example, a verb like fregar (scrub) lexically specifies a manner which suggests contact with a surface and motion, and this action is typically used with the intention of removing something from a surface. But in certain contexts this removal is difficult to imply, therefore, the authors conclude that if it can be explicitly denied, it is not lexically codified within the verb and thus, is a cancelable implicature: fregué la cacerola durante horas, pero no la dejé más limpia (I scrubbed the tub for hours, but it didn't get any cleaner).

In the same way, result verbs such as limpiar (clean) codify states that often, though not always, are the result of actions carried out in order to remove a substance from a surface or container. In a given context, a specific action will be difficult to imply, as in limpié la cacerola, $y$, como de costumbre, usé un estropajo de alumnio (I cleaned the tub and, as usual, I used a scouring powder). Again, it is assumed that no particular action is lexically specified, as proven by the possibility of providing different endings that do explicitly show the action implied.

Therefore, according to Levin and Rappaport (2008), a causative change of state verb such as limpiar (clean) has a result root which specifies a state that often comes as a result of an activity, whereas the verb fregar (scrub) has a result which specifies an activity, and in many examples, the activity is conventionally carried out in order to achieve a particular result. With fregar (scrub) the result is "cleanliness", which explains the intuition of the relation between the manner verb fregar (scrub) and the result verb limpiar (clean). 


\section{[[X ACTIVITY $<M A N N E R>]$ CAUSE [BECOME [Y <LIMPIO (CLEAN)>]]] [X ACTIVITY $<$ FREGAR (SCRUB)>]}

Result verbs specify the achievement of a result state, a state that is the result of some kind of activity, and it is this state which is lexicalized in the root. So, the verbs limpiar (clean) and vaciar (empty) describe two different result states which are often achieved by removing a substance from somewhere, but neither of the verbs is specific about how the relevant result state comes about. Result verbs, according to Rappaport and Levin, denote eventualities caused externally, i.e., they are associated with causative change of state lexical conceptual structures.

A manner root is associated to an activity's lexical conceptual structure (Levin and Rappaport, 2008): such roots describe actions which are identified using some kind of means, manner or instrument. Therefore, manner verbs such as fregar (scrub) or cepillar (brush) describe actions that imply contact being applied to a surface, but they differ in the way the action is carried out on the surface and the degree of force and intensity of motion involved. Often such activities are characterized, especially in English, by the instrument used to carry them out and the name of the verb itself derives from the name of the instrument: cepillar (brush), rastrillar (rake), etc.

Rappaport and Levin (2008) have suggested another difference between manner and result verbs according to the notions of scalar and non-scalar change. As dynamic verbs, all manner and result verbs imply change, although not of the same kind: result roots specify scalar change whereas manner roots do not. Verbs which denote scalar change events in an argument lexically imply a scale, that is, a series of degrees, points or intervals that indicate measurements organized in a particular dimension which represents an argument attribute, and in which the degrees represent the possible values the attribute can adopt. A scalar change in a entity suggests a change in the value of the relevant attribute following a particular direction along the associated scale. The change of state verb ensanchar (widen) is associated with a scale of increasing values in a width dimension, and a widening event necessarily requires that a body show an increase in value along this dimension. A non-scalar change is a change that cannot be characterized in terms of a scale. These changes are generally complex and imply a combination of various changes at a time. This is typically the case, as has already been mentioned, with manner verbs. So, for example, the verb barrer (sweep) implies a specific motion of a sweeping brush against the floor which is repeated an indefinite number of times.

\subsection{Further aspects involving manner and result components}

Rappaport and Levin's proposal is very interesting but difficult to carry out. In this respect, it may be convenient to consider the aspects observed by Di Tullio (2002) and Moreno Cabrera (1998 and 2003) which are in some way related.

Di Tullio (2002), who considers works prior to Levin and Rappaport, also acknowledges that verbs which show locative alternation lexicalise a manner component that indicates the manner in which the change that affects location occurs. However, Di Tullio points out that the manner component should be aimed towards the agent, not the patient. For example, rociar (spray) means the way the agent carries out the action of spreading liquid over an 
object, whereas salpicar (splash), which does not alternate (salpicó la mesa de cerveza (he splashed the table with beer)/ *salpicó la cerveza en la mesa (he splashed beer on the table)), indicates the manner in which the liquid is distributed over an object, with no necessary reference as to the agent or cause of the event (which explains why some locative constructions, such as ha salpicado pintura en el mueble (he splashed paint on the furniture), are possible, normally without a specific agent, but with a certain degree of impersonality). However, though Di Tullio's and Levin and Rappaport's explanations may seem different, I see them as exactly the same, but with different terminology. Salpicar (splash), for Levin and Rappaport, is similar to a verb like llenar (fill), a verb that only indicates a result state, where the manner affects the patient, not the agent. It is a non-location verb which specifies that a given element (cerveza-beer) occupies a given object/location, but never is the possibility for a change of position by the figure considered. Although in order to achieve the result specified by salpicar (splash) we are aware that a change of location is necessary, even though it is not expressed.

Moreno Cabrera $(1998,2003)$ also comments on locative alternation restrictions and comes up with examples such as:

Esparció arena en el porche / *esparció el porche de arena.

(He spread sand on the porch / "he spread the porch with sand.)

* Llenó agua en el vaso / llenó el vaso con agua.

(*He filled water in the glass / he filled the glass with water.)

Moreno Cabrera considers that in these examples there is both a change of location and a characterization of the result state. With the verb esparcir (spread) we not only indicate that an object or substance, such as sand, has been moved, but that the way in which the substance is placed is also expressed: it is disseminated. As for llenar (fill), he considers that not only is it indicated that a substance is inside a given container, but also that the substance occupies it entirely. The idea of result versus manner seems, then, to be the key differentiating element. However, certain aspects are worth considering: a) verbs such as llenar (fill) do not indicate location, merely result state, and according to Moreno Cabrera, it could be understood that location is indicated, as well as result state. b) Esparcir (spread) indicates location, and the manner it implies seems to affect only the non-actor objects, and not the agent (in Di Tullio's terms), so it could be said that it does not indicate manner in the sense we are dealing with here, but the manner in which an object (sand) is distributed in a location.

However, the difference between when a construction indicates location and manner according to the agent, which would imply alternation, and when it indicates location and manner according to the patient, or result state, which would not alternate, is unclear. Take verbs like esparcir (spread), sembrar (sew) and grabar (etch). Esparcir (spread) allows locative constructions but not the con (with) variant. On the other hand, sembrar (sew) and grabar (etch) do allow alternation. We may accept that esparcir (spread) implies location and result state but, in my opinion, the same can be said of sembrar (sew) and grabar (etch): in both cases what is sewn or etched implies manner according to the patient, not the agent.

Moreno Cabrera introduces another difference which, if taken in conjunction with the previous one, would be a deciding factor: the noun phrase that plays the object in each of the alternating constructions should express the participle of the main verb and, if this is not 
the case, the sentence becomes grammatically incorrect. That is to say that the direct object expresses the property conveyed by the participle of the verb that takes it, but if the noun phrase that is meant to cannot express that property, it can not act as a direct object. But this will not help us differentiate and distinguish between manner and result.

Cargó leña en el carro / cargó el carro con leña. (He loaded wood on to the cart / he loaded the cart with wood.)

Rocio pintura sobre la pared / rocio la pared con pintura. (He sprayed paint on the wall The sprayed the wall with paint.)

Vació el tanque de agua / vació el agua del tanque. (He emptied the tank of water / he emptied the water from the tank.)

*Llenó el agua en el vaso / llenó el vaso de agua. (He filled the water into the glass / he filled the glass with water.)

Puso la maceta en la puerta / *puso la puerta con la maceta. (He put the plant pot by the door / the put the door with the plant pot.)

Esparció arena en el porche/*esparció el porche con arena (He spread sand on the porch / he spread the porch with sand.)

La leña está cargada en el carro / el carro está cargado con leña (The wood is loaded on to the cart / the cart is loaded with wood.)

La pintura está rociada sobre la pared / la pared está rociada con pintura (The paint is sprayed on the wall / the wall is sprayed with paint.)

El tanque está vaciado de agua / el agua está vaciada del tanque (The tank is emptied of water / the water is emptied from the tank.)

*El agua está llenada/lena en el vaso / el vaso está llenado/lleno de agua (*The water is full/filled in the glass / the glass is fullifilled with water.)

La maceta está puesta en la puerta / *la puerta está puesta con la maceta (The plant pot is put by the door / the door is put with the plant pot.)

La arena está esparcida en el porche /*el porche está esparcido con arena (The sand is spread on the porch /*the porch is spread with sand.)

The above correlations are very interesting, and correct, but I do not think they can be used to explain absolutely anything since they do not provide us with an answer as to the criteria required for some verbs to allow alternation and others not to. They are merely proof of a combination that reflects alternation. However, let us consider examples such as the following:

Rellenar los espacios en los formularios (Filling in blanks in forms)

Llenar un hueco en su vida (Filling a gap in one's life)

Los espacios están rellenados / los formularios están rellenados (The gaps are filled / the forms are filled-in)

El hueco está llenado-lleno / su vida está llenada-llena (The gap is filled-full / one's life is filled-full)

According to the evidence provided by Moreno Cabrera, llenar (fill) and rellenar (fill in) ought to alternate, bearing in mind the meanings shown in the examples, but they do not:

Rellenar los espacios en los formularios / "rellenar los formularios con-de espacios (Fill in the blanks in the forms / *fill in the forms with-of the blanks)

Llenar un hueco en su vida / *llenar su vida con-de un hueco (Fill a gap in your life /*fill your life with-of a gap) 
Furthermore, these examples seem to contradict what was previously said about llenar (fill). As a result verb, it did not allow the en (in) alternation, but these examples-prove just the opposite. Explanations could come from all sides: a) the meaning of rellenar (fill in) in the example is not that of "re-filling" something, as it could be in the original Spanish example; b) llenar (fill) has an abstract meaning; c) both cases show a pre-existing part/ whole relation between content and container: forms are not filled in with blanks, nor is life filled with gaps, whereas bottles are re-filled or filled with liquid, and proof of this could be that the preposition en (in) alternates with $d e(o f)$, which means that the preposition phrase becomes a noun complement and not a location. Neither of the examples shows a location relation between a figure (espacios-space/hueco-gap) and a base (en los formularios (in forms)/en su vida (in life)); they show a result action (rellenar los espacios (fill in blanks)/ llenar un hueco (fill a gap)) which does have a location because the result state is a preexisting part of a whole, forming a kind of inalienable possession.

Furthermore, although for different reasons, there is a group of verbs which, in Spanish, can alternate despite not following the pattern drawn out by Moreno Cabrera whereby the noun phrase, which is the object of each alternating construction, must be able to express the past participle of the corresponding main verb, otherwise the sentence would be grammatically incorrect.

$$
\begin{aligned}
& \text { Tengo granos en la cara / tengo la cara con granos (I have spots on my face / I have my } \\
& \text { face with spots) } \\
& \text { Llevo un roto en el pantalón / llevo el pantalón con un roto (I have a hole in my trousers } \\
& \text { / I have my trousers with a hole) } \\
& \text { *Los granos están tenidos / *la cara está tenida (*The spots are had/*the face is had) } \\
& \text { *El roto está llevado / *el pantalón está llevado (*The hole is had/*the trousers are had) }
\end{aligned}
$$

In spite of all the previous analyses, I am under the impression that the difference between manner and result verbs is still not clear ${ }^{8}$, and that there is a need for more definite syntactical evidence in order to distinguish correctly. And in any case, there is not a clear correlation between verbs that alternate and verbs that do not. The first proposal was that alternating verbs had to be manner verbs and, seeing as manner and result verbs are complementary, result verbs were therefore unable to alternate. The truth, however, is that there are result verbs that imply alternation, such as vaciar (empty) and limpiar (clean). On the other hand, there are verbs which are hard to classify as manner or result. Such is the example of atascar (jam) and aprisionar (stick) which, though they seem like result verbs, would require an explanation as to why one, atascar (jam), can alternate whereas aprisionar (stick) can not.

\begin{abstract}
Atascó una compresa en la tubería / atascó la tubería con una compresa (He jammed a sanitary towel in the pipe / he jammed the pipe with a sanitary towel)

Aprisionó una compresa en la tuberia / "aprisionó la tuberia con una compresa (He stuck a sanitary towel in the pipe / *he stuck the pipe with the sanitary towel)

La compresa está atascada / la tubería está atascada (The sanitary towel is jammed/the pipe is jammed)
\end{abstract}

8 We must bear in mind that Levin and Rappaport established their proposal for English only, and here we are discussing Spanish, and thus have no intention of denying the validity of these author's proposal. 
La compresa está aprisionada / *la tuberia está aprisionada (The sanitary towel is stuck $/$ *the pipe is stuck)

The only explanation to differentiate them is that atascar (jam) is a denominal locatum verb and aprisionar (stick) is a denominal location verb (Cifuentes, 2005).

From a different perspective, Levin and Rappaport pointed out that if the root of some verbs describes a manner used to obtain a very specific result they would not allow a series of alternations. Their example was aspirar (vacuum), and indeed the examples we used earlier do illustrate this restriction in their theory (aspiró el polvo de la alfombra the vacuumed the dust from the carpet) / "aspiro la alfombra con/de polvo (he vacuumed the carpet with/of dust)), but there are examples with aspirer (vacuum) that confirm the ability to alternate and which therefore legitimize considering the manner component to be a deciding factor for alternation.

Aspiró los ácaros de la alfombra (he vacuumed the mites from the carpet).

Aspiró la alfombra de ácaros (he vacuumed the carpet of mites).

\section{Types of verbs with locative alternation}

And so it would seem that Levin and Rappaport's restriction whereby verbs with a manner component allow locative object alternation could extend to Spanish also. The main problem lies in explaining why many other verbs that do not have a manner component, but rather a result component, for example, still alternate, in the same way as there are verbs that do not imply a change of state and alternate as well. It is for this reason, I believe, that explaining locative alternation should not be seen as something general for all verb types, but that the explanation should be sought for each of the subtypes of alternation proposed (Cifuentes, 2009).

I. Alternation involving locative complements and oblique complements beginning with con (with):

a. Predicative alternations. In Spanish, there is a relation between the locative transitive construction, which is possessive (llevaba una mancha en el zapato - he had a stain on his shoe--), and the predicative construction (llevaba el zapato con una mancha - he had a shoe with a stain-) through the concept of attribution. In the locative construction, the fact that the locatum object is on the location object following a content/container relation, which also implies result, could be a property or feature of the localizing object. This means that it could be expressed using a predicative construction with its various possibilities, the most interesting being the oblique form using the con (with) $X$ construction. The predicative complement introduces the way of being of the possession, the part or something that belongs to, or is associated with, the subject. The verb has a predicative possessive value in the locative construction which is why there are verbs that alternate and other that do not:

Llevaba una mancha en el zapato / llevaba el zapato con una mancha (He had a stain on his shoe / he had a shoe with a stain) 
Se puso una tirita en la cara / *se puso la cara con una tirita (He put a plaster on his face / the put his face with a plaster)

In the example with the verb llevar (have/wear/take), the verb is not classed as a motion verb since there is nowhere to go to or come from ${ }^{9}$. In the poner (put) example, the verb has locative position change values. Llevar (have) indicates possession, poner (put) indicates location.

Therefore, in predicative alternations it is neither the manner component nor the result component which determines whether or not the alternation is acceptable; it depends on the pragmatic possibility of identifying a way of being of a given object through one of its properties.

Tiene un grano en la cara / ?tiene la cara con un grano (He has a spot on his face /*he has his face with a spot)

Tiene granos en la cara / tiene la cara con granos (He has spots on his face/"he has his face with spots)

Tiene la lámpara en el suelo / ?tiene el suelo con una lámpara (He has the lamp on the floor / the has the floor with a lamp)

Tiene libros en el baño / tiene el baño con libros (He has books in the bathroom / *he has the bathroom with books)

It is hard to think that a spot might pragmatically characterize anyone's face. We can think of expressing the fact that there is a spot on a face, but not of characterizing the face as having a spot. It is another story if there are lots of spots, in which case it could be the way of being of a face. A spotty face is a kind of face, a face with one spot is not. Equally, it is difficult to conceive identifying the floor just because of the anecdote that the lamp is on it or the bathroom because there is a book in it. However, if there are a lot of books in the bathroom, that is to say that it is a bathroom with books and that this is one of its properties, the alternation would be allowed in Spanish.

Therefore, in predicative constructions, alternation is not determined by manner or result components (although the idea of manner and result is linked with the notion of secondary predication), but by the type of complement.

b. Ablative alternations. It is a well-known fact that not all removal verbs allow alternation. However, in this group of verbs it is not possible to differentiate between manner and result verbs because if the verb expresses any kind of manner, even if it leads to a result, like vaciar (empty) or limpiar (clean), it will allow alternation:

Limpió el polvo del salón (he cleaned the dust in the sitting room).

Limpió el salón de polvo( he cleaned the sitting room of dust).

The only verbs that will not alternate are those that do not lexicalize a manner component, and therefore are only able to be expressed in a locative fashion:

9 The Spanish verb llevar can be translated in various ways, including to take or carry, which would be considered motion verbs, and to wear or to have, which would not. 
quitar (remove) is a verb that does not alternate: quitó el polvo de la mesa / *quitó la mesa de-con polvo (he removed the dust from the table / *he removed the table of -with dust). But quitar is a verb which always lexicalizes a directional component, which is clear because of the fact that the directional component is always present, be it syntactically or contextually. However, with removal verbs that have a manner component, it is possible to express them without the path component: it is possible to conceive and to express emptying the bottle regardless of the origin or destination of the figure, without having to conceptualize it, because it only appears as a manner verb. The same occurs with all manner removal verbs, such as aspirar (vacuum): aspiró la alfombra (he vacuumed the carpet). In this example, no-one wonders what is the origin or destination of the figure, merely the action, whether it is manner, or result through manner. Thus, with this type of verb, the manner component, whether a type of action or a result, is the fundamental element whose lexicalization allows locative alternation.

c. Constructed object and image impression alternations. All constructions seem to come about thanks to a type of verb which implies constructing something that did not exist beforehand (content) in a given location (container), whether it is physically (urbanizar - build -), mentally (idear - devise -) or emotionally (querer -want-). In all cases, there are alienable possessions brought about by location, but possession-location is only possible (because it is alienable) thanks to the action of the verb, that is, as a result of verbal activity, otherwise it would never be póssible to conceive possession. Therefore, the concepts of result and manner are still vital.

Edificó la primera linea de playa con adosados ("he built the beachfront with semi-detached houses).

Edificó adosados en la primera linea de playa (he built semi-detached houses on the beachfront)

Grabó la pluma con la fecha señalada (he engraved the fountain pen with the appropriate date). Grabó la fecha señalada en la pluma (he engraved the appropriate date on the fountain pen).

According to Iwata (2008: 95), verbs that take locative alternations are a continuum based on the type of semantic event in each of the verb meanings, going from the container event to the covering a surface event. This is even clearer in Spanish bearing in mind that in Spanish surfaces are conceptualized as contain$\mathrm{ers}^{10}$. When it comes to verbs that take this sort of alternation, the covering event, rather than the container/content event is the vital element.

d. Denominal locatum verb alternations. Not all denominal locatum verbs allow alternation, partly because not all denominal locatum verbs develop an oblique compliment. As we pointed out previously (Cifuentes, 2005; 2006a) there are two types of nominal incorporation: one in which the noun's syntactical function is completely covered by the verb itself (excarceló a los presos etarras (they excarcerated the ETA prisoners)/*excarceló a los presos etarras de la cárcel

10 Vid. Cifuentes Honrubia 1996: chapter II. 
(*they excarcerated the ETA prisoners from prison) and a second type where the verb requires an element correlated to the incorporated noun (el barco encallo entre las rocas -the boat got stuck in the rocks-), which would justify the fact that denominal locatum verbs and location verbs could somehow be able to syntactically repeat the incorporated element: if the incorporated noun did not satisfy the verb's argument it would semantically link to another syntactically given element. There are different kinds of semantic links, but the most common is subspecification where the syntactical argument refers to a specific, concrete, definite type of the incorporated noun, which is always more generic. The more natural the sub-specification is, the more common and normal it sounds in the given language, the easier the alternation will be. From the moment sub-specification is feasible, the alienable link of possession between the direct object and the oblique complement comes into being, hence it being considered a container-content relation. Once this has been established, it is possible to consider a change of focus of the action, from a locative-possessive perspective, involving a construction with an oblique object (introduced by con (with) or, sometimes, de (off), to a locative perspective, involving a construction with a locative preposition. And so, alternation is feasible with this group of verbs, and the manner or result element could surely be traced in their meaning but alternation occurs, apparently, regardless of these elements:

Ensillo el caballo con una manta (he saddled the horse with a blanket). Ensillo una manta en el caballo (?he saddled a blanket on the horse).

e. Verb and prepositional element conflation alternations. With this type of verb it is possible to generalise the idea that they allow alternation in all circumstances, and, as with the previous subgroup, the manner and result elements, though they may be present, are irrelevant, despite the fact that manner may be expressed by the relating object:

Encabezó a los sublevados en la revuelta (he led the rebels in the revolt). Encabezó la revuelta con los sublevados (he led the revolt with the rebels).

f. Surrounding alternations. There is a very limited group of verbs that allow constructions where the container/content schema is sub-edited by the idea of surrounding: there is not one element inside another, but one element around another. Therefore, their main determining feature is the manner in which the action takes place, which we have labelled surrounding:

Enrolló el paquete con una toalla (he wrapped the package with a towel).

Enrollo una toalla alrededor del paquete (he wrapped a towel around the package).

II. Locative alternation without the with variation.

g. Partitive alternation. The group of verbs that allow this sort of alternation are those characterized as such by Cifuentes (2004): these are verbs that imply 
the verbal conflation of the figure component in the motion/location event. The figure can be represented both by a noun that leads to the denominal verb or by a noun derived from the verb: arañar $>$ arañazo (to scratch $>a$ scratch), herir $>$ herida (to wound $>a$ wound), vara $>$ varear (a cane $>$ to cane), zapato>zapatear (a shoe $>$ to shoe):

Le mordio la oreja (it bit his ear) / le mordio en la oreja (it bit him on the ear).

Le zapateó el trasero (he shoed his behind) / le zapateó en el trasero ("he shoed him on the behind).

In Spanish, all of these verbs can be paraphrased analytically (golpear/dar un golpe - hit/"give a hit-, morder/dar un mordisco - bite/give a bite-, etc.), and the inherent object becomes the location figure. When expressed synthetically, they represent the way an action is carried out. In direct structures the manner or way of carrying out the action is expressed, but locative conceptualization is not. However, the group of verbs we are looking at can express locative conceptualization by using a prepositional phrase beginning with en (in). Therefore, this type of verb can be categorized in two ways: as the manner in which the action is carried out affecting an object, or as the manner in which the action is carried out affecting a location; this object/location convertibility explains why one manner or another can be expressed. Equally relevant is the fact that the object/location is a human body part. When the way the action is carried out affects how the object is considered, the internal object, which is necessary as a figure for location, is not seen as relevant.

Accusative/partitive verbs imply conceptualizing three basic processes: a) factive: the action is carried out somewhere on the body: herir (wound), quemar (burn), arañar (scratch). b) Transference: a process in which the sender transfers a given event to the receiver (where the action takes place) making him feel the effect of the action: besar (kiss), golpear (hit), morder (bite), azotar (slap). c) Instrument location: in this case the action is carried out with the aid of an instrument, which is the noun that represents the figure and that the verb derives from, causing a given effect upon the receiver: varear (cane), fustigar (whip), zapatear (shoe). The group of verbs that allow this kind of construction, despite being very varied, can be reduced to a few subgroups, bearing in mind that they must include interaction with some part of the body:

a. Verbs that imply some sort of bump or stroking action: acariciar (stroke), arañar (scratch), azotar (whip), besar (kiss), besuquear (smother with kisses), fustigar (whip), golpear (hit), herir (wound), hurgar (rummage), morder (bite), paporrear (beat), pellizcar (nip), pizcar (pinch), picar (sting), picotear (peck), pinchar (prick), pisar (tread), punzar (pierce), quemar (burn), rascar (scratch), repizcar (pinch), varear (cane), zapatear (shoe), zurrar (beat).

b. Verbs that imply some sort of stain or substance, whether to apply or to remove it: pintar (paint), untar (spread), manchar (stain), ensuciar (dirty), limpiar (clean).

c. Verbs linked to the senses with which one can perceive a figure in the action: mirar/mirada (gazela gaze), tocar (touch), palpar (feel), oler (smell), olfatear (scent), olisquear/olor (sniffla smell), chupar/chupetón (lick/a lick). 
In all of these examples, the manner component is present, though not significant.

h. Directional partitive alternations. The schema that underlies these constructions is always a transference (that takes its schema from motion, that is, from locative transference), either locative or abstract transference, in which the actor violently moves a figure, forcing the receiving object to be constructed along with the preposition contra (against). The manner implied by the verb allows the transference structure to alternate with another structure which expresses the result of the action, and the instrument becomes the element with which the manner of action is achieved:

Embistio el coche contra la valla (he rammed the car against the fence).

Embistio la valla con el coche (he rammed the fence with the car).

This type of construction is based on the same location/attribution schema that the previous groups are based on. In the violent transference construction, the localized object (figure represented by the direct object) can be found in/on the localizing object (receiver, the base that is the target of the transference) following the container/content process common to all transferences. This also implies result, which can be understood to be a manner or way of carrying out the action which consequently can be conceived not just as a transference (embestir el coche contra la valla -ramming the car against the fence-), but as a result (embestir la valla - ramming the fence--). Here the instrument introduced by the preposition with is the defining element in order to achieve the action; it points out the property (instrument) necessary for the action expressed to take place.

i. Possessive alternations. Verbs that allow this kind of alternation differ in that they do not represent activity, but a type of volitive experience. They are therefore related to predicative alternation verbs in that in every case there seems to be a secondary locative-possessive predication based on a locative container relation. And in turn, this possessive predication, based on a locative container relation, expresses the action in question, which may be profile in different ways. The idea of manner, then, and especially of result, lies in the significant value of the constructions these verbs are part of:

Admiro en Cristina su bondad e inocencia (*I admire in Christine, her kindness and innocence).

Admiro la bondad e inocencia de Cristina (I admire Christine's kindness and innocence). Admiro Cristina porlen su bondad e inocencia (I admire Christine for her kindness and innocence).

j. Reciprocal alternations. It is common in language to find verbs that allow this sort of reversibility, and of these verbs that take reciprocal alternation, there is a subgroup that have a locative meaning and thus, their alternation is due to reversibility. It is clear that these verbs imply manner and result, but what truly defines them is the notion of reversibility:

Apartó al niño del padre (he separated the child from his father). Apartó al padre del niño (he separated the father from his child). 
Therefore, although manner and result are important, they must be considered in a wider sense, such as the one used in our typological classification, in order to correctly distinguish cases of alternation from other cases of verbs that do not alternate.

\section{Removal verbs in Spanish}

Most examples of locative alternation in Spanish have a certain adlative sense, meaning there is a certain added or sudden change to an existing situation. There is an interesting group of constructions that are characterized by the removal of an element in a given situation.

As we mentioned earlier, from the point of view of meaning Levin and Rappaport (1991: 145) suggest that removal verbs can be considered the opposite to verbs such as cargar (load) or rociar (spray). Cargar (load) and rociar (spray) verbs describe the location of a figure, or locatum, in a certain location (which works as a base or background). Removal verbs such as limpiar (clean) can be characterized, in general terms, by the removal of a locatum element from a location. The ability to express location either as a direct object or using an oblique phrase is probably the most important property that removal verbs such as limpiar (clean) share with typical alternating verbs such as cargar (load) and rociar (spray). Furthermore, it is this very property that suggests that they are all part of a bigger group of verbs with locative alternations.

Despite the fact that they do not allow the con (with) alternation, this group of verbs can certainly be considered complementary to those that do since, contrary to the rest that express an adlative orientation, removal verbs express the same kind of relations but in an ablative fashion.

With respect to removal verbs, Levin and Rappaport also suggest the idea of one basic construction and one derived construction, as is the case with con (with) alternating verbs used in an adlative sense. These two authors consider (1991:140) that both variants are linked through the "by means of" relation because a removal verb like limpiar (clean) basically means "take away by means of a change of state that makes another object clean". Consequently, they deem that it is the locative variant (wipe the dust off the table), the one whose locatum is the direct object, which derives from the non-stative variant, a change of state with a result of cleanliness (limpiar la mesa de polvo -wipe the table of dust-), where the location element is the direct object ${ }^{11}$. Iwata also accepts the idea of considering removal verbs to be in the same group as locative con (with) alternations (2008) and points out some of the differences between both types of construction (2008: 135), including the fact that there are very few removal verbs with locative alternations (more specifically, he discusses four). But this is not the case in Spanish, where the group is significantly large. He also points out that the above mentioned idea, that some verbs only allow constructions with a location complement and others only allow the con (with) complement construction, is not

11 This is quite the opposite to verbs like cargar (load) and rociar (spray). With cargar (load) and rociar (spray) the basic variant is the one whose locatum is the direct object (cargo leña en el carro -he loaded wood onto the cart-), and the second variant is derived from it, with location as the direct object (cargo el carro con leña -he loaded the cart with wood-). However, considering and analysing the idea of basic meaning and derived meaning ought to be rethought because, from a historical point of view, it is certainly doubtful. 
true in the case of removal verbs, arguing that, though it may be possible to find verbs that prove only to allow the locative variant, there are no verbs that prove the other variant, at least not in English, and it is also difficult to conceive them in Spanish.

Therefore, removal verbs can be considered complementary to the group of alternating verbs with locative variants and con (with) variants. Furthermore, the possession-location relation they focalize will not occur as a result of the action. Rather this relation already exists, it is the starting point, and the result of the action is in fact bringing that possessionlocation relation to an end:

\begin{tabular}{|c|c|}
\hline $\begin{array}{l}\text { Absolver los pecados de su alma } \\
\text { (Absolve the sins from his soul) }\end{array}$ & $\begin{array}{l}\text { Absolver su alma de pecados } \\
\text { (Absolve his soul of sins) }\end{array}$ \\
\hline $\begin{array}{l}\text { Aclarar el jabón de la ropa } \\
\text { (Rinse the soap from the clothes) }\end{array}$ & $\begin{array}{l}\text { Aclarar la ropa de jabón } \\
\text { (Rinse the clothes of soap) }\end{array}$ \\
\hline $\begin{array}{l}\text { Afeitar los pelos del pecho } \\
\text { (Shave hairs from one's chest) }\end{array}$ & $\begin{array}{l}\text { Afeitar el pecho de pelos } \\
\text { (Shave one's chest of hairs) }\end{array}$ \\
\hline $\begin{array}{l}\text { Aspirar los ácaros de la alfombra } \\
\text { (Vacuum the mites from the carpet) }\end{array}$ & $\begin{array}{l}\text { Aspirar la alfombra de ácaros } \\
\text { (Vacuum the carpet of mites) }\end{array}$ \\
\hline $\begin{array}{l}\text { Barrer las migajas del salón } \\
\text { (Sweep the crumbs in the living room) }\end{array}$ & $\begin{array}{l}\text { Barrer el salón de migajas } \\
\text { (Sweep the living room of crumbs) }\end{array}$ \\
\hline $\begin{array}{l}\text { Bombear el agua del tanque } \\
\text { (Pump water from the tank) }\end{array}$ & $\begin{array}{l}\text { Bombear el tanque de agua } \\
\text { (*Pump the tank of water) }\end{array}$ \\
\hline $\begin{array}{l}\text { Cepillar las migajas de la chaqueta } \\
\text { (Brush the crumbs from the jacket) }\end{array}$ & $\begin{array}{l}\text { Cepillar la chaqueta de migajas } \\
\text { (*Brush the jacket of crumbs) }\end{array}$ \\
\hline $\begin{array}{l}\text { Chupar el chocolate de los dedos } \\
\text { (Lick chocolate from one's fingers) }\end{array}$ & $\begin{array}{l}\text { Chupar los dedos de chocolate } \\
\text { (*Lick one's fingers of chocolate) }\end{array}$ \\
\hline $\begin{array}{l}\text { Depilar los pelos del pecho } \\
\text { (Epilate hairs from one's chest) }\end{array}$ & $\begin{array}{l}\text { Depilar el pecho de pelos } \\
\text { (Epilate one's chest of hairs) }\end{array}$ \\
\hline $\begin{array}{l}\text { Desatascar las compresas de la tubería } \\
\text { (Clear the sanitary towels from the pipe) }\end{array}$ & $\begin{array}{l}\text { Desatascar la tubería de compresas } \\
\text { (Clear the pipe of sanitary towels) }\end{array}$ \\
\hline $\begin{array}{l}\text { Descargar la leña del carro } \\
\text { (Unload the wood from the cart) }\end{array}$ & $\begin{array}{l}\text { Descargar el carro de leña } \\
\text { (Unload the cart of wood) }\end{array}$ \\
\hline $\begin{array}{l}\text { Desempolvar el polvo del armario } \\
\text { (Dust the dust from the cupboard) }\end{array}$ & $\begin{array}{l}\text { Desempolvar el armario de polvo } \\
\text { (Dust the cupboard of dust) }\end{array}$ \\
\hline $\begin{array}{l}\text { Desescombrar los ladrillos rotos de la obra } \\
\text { (Take the broken bricks from the building site) }\end{array}$ & $\begin{array}{l}\text { Desescombrar la obra de ladrillos rotos } \\
\text { (*Take the building site of broken bricks) }\end{array}$ \\
\hline $\begin{array}{l}\text { Deshollinar las cenizas de la chimenea } \\
\text { (Sweep the soot from the chimney) }\end{array}$ & $\begin{array}{l}\text { Deshollinar la chimenea de cenizas } \\
\text { (Sweep the chimney of soot) }\end{array}$ \\
\hline $\begin{array}{l}\text { Desincrustar todo tipo de grasa de la tubería } \\
\text { (Unstick all kinds of grease from the pipe) }\end{array}$ & $\begin{array}{l}\text { Desincrustar la tubería de todo tipo de grasa } \\
\text { (*Unstick the pipe of all kinds of grease) }\end{array}$ \\
\hline $\begin{array}{l}\text { Desmantelar los muebles de la habitación } \\
\text { (Dismantle the furniture from the room) }\end{array}$ & $\begin{array}{l}\text { Desmantelar la habitación de muebles } \\
\text { (*Dismantle the room of furniture) }\end{array}$ \\
\hline $\begin{array}{l}\text { Desmontar las piezas pequeñas del reloj } \\
\text { (Take apart the small pieces of the watch) }\end{array}$ & $\begin{array}{l}\text { Desmontar el reloj de piezas pequeñas } \\
\text { (*Take the watch apart of small pieces) }\end{array}$ \\
\hline
\end{tabular}




\begin{tabular}{|c|c|}
\hline $\begin{array}{l}\text { Desocupar los libros de la estantería } \\
\text { (Empty the books from the shelf) }\end{array}$ & $\begin{array}{l}\text { Desocupar la estantería de libros } \\
\text { (Empty the shelf of books) }\end{array}$ \\
\hline $\begin{array}{l}\text { Despejar los trastos de la habitación } \\
\text { (Clear the junk from the room) }\end{array}$ & $\begin{array}{l}\text { Despejar la habitación de trastos } \\
\text { (Clear the room of junk) }\end{array}$ \\
\hline $\begin{array}{l}\text { Destilar los nitratos del agua } \\
\text { (Distill nitrates from water) }\end{array}$ & $\begin{array}{l}\text { Destilar el agua de nitratos } \\
(* \text { Distill water of nitrates) }\end{array}$ \\
\hline $\begin{array}{l}\text { Desviar el tráfico de la carretera } \\
\text { (Divert traffic from the road) }\end{array}$ & $\begin{array}{l}\text { Desviar la carretera de tráfico } \\
\text { (*Divert the road of traffic) }\end{array}$ \\
\hline $\begin{array}{l}\text { Dragar las minas del terreno marcado } \\
\text { (Sweep the mines from the marked land) }\end{array}$ & $\begin{array}{l}\text { Dragar el terreno marcado de minas } \\
\text { (Sweep the marked land of mines) }\end{array}$ \\
\hline $\begin{array}{l}\text { Eliminar los malos olores de la casa } \\
\text { (Eliminate odours from one's house) }\end{array}$ & $\begin{array}{l}\text { Eliminar la casa de malos olores } \\
\text { (*Eliminate one's house of odours) }\end{array}$ \\
\hline $\begin{array}{l}\text { Enjugar los gérmenes de la boca } \\
\text { (Swill germs from one's mouth) }\end{array}$ & $\begin{array}{l}\text { Enjugar la boca de gérmenes } \\
\text { (Swill one's mouth of germs) }\end{array}$ \\
\hline $\begin{array}{l}\text { Esquilar la lana de las ovejas } \\
\text { (Shear the wool from the sheep) }\end{array}$ & $\begin{array}{l}\text { Esquilar las ovejas de lana } \\
\text { (Shear the sheep of wool) }\end{array}$ \\
\hline $\begin{array}{l}\text { Exprimir el zumo de la naranja } \\
\text { (Squeeze the juice from the orange) }\end{array}$ & $\begin{array}{l}\text { Exprimir la naranja de zumo } \\
\text { (Squeeze the orange of juice) }\end{array}$ \\
\hline $\begin{array}{l}\text { Filtrar el agua de la cubeta } \\
\text { (Filter the water from the tank) }\end{array}$ & $\begin{array}{l}\text { Filtrar la cuberta de agua } \\
\text { (Filter the tank of water) }\end{array}$ \\
\hline $\begin{array}{l}\text { Fregar las manchas del suelo } \\
\text { (Mop the stains from the floor) }\end{array}$ & $\begin{array}{l}\text { Fregar el suelo de manchas } \\
\text { (Mop the floor of stains) }\end{array}$ \\
\hline $\begin{array}{l}\text { Frotar las manchas del sofá } \\
\text { (Scrub the stains from the sofa) }\end{array}$ & $\begin{array}{l}\text { Frotar el sofá de manchas } \\
\text { (Scrub the sofa of stains) }\end{array}$ \\
\hline $\begin{array}{l}\text { Lavar las manchas de los cubiertos } \\
\text { (Wash the dirt from the cutlery) }\end{array}$ & $\begin{array}{l}\text { Lavar los cubiertos de manchas } \\
\text { (Wash the cutlery of dirt) }\end{array}$ \\
\hline $\begin{array}{l}\text { Lijar los desperfectos de la tabla } \\
\text { (Sand the defects on the plank) }\end{array}$ & $\begin{array}{l}\text { Lijar la tabla de desperfectos } \\
\text { (Sand the plank of defects) }\end{array}$ \\
\hline $\begin{array}{l}\text { Limpiar el polvo del salón } \\
\text { (Clean the dust from the sitting room) }\end{array}$ & $\begin{array}{l}\text { Limpiar el salón de polvo } \\
\text { (Clean the sitting room of dust) }\end{array}$ \\
\hline $\begin{array}{l}\text { Liquidar a los jefes de la banda } \\
\text { (Kill the leaders of the gang) }\end{array}$ & $\begin{array}{l}\text { Liquidar la banda de jefes } \\
\text { (*Kill the gang of leaders) }\end{array}$ \\
\hline $\begin{array}{l}\text { Podar las ramas viejas del árbol } \\
\text { (Prune the old branches from the tree) }\end{array}$ & $\begin{array}{l}\text { Podar las el árbol de ramas viejas } \\
\text { (Prune the tree of old branches) }\end{array}$ \\
\hline $\begin{array}{l}\text { Prevenir los peligros de la escapada } \\
\text { (Avoid the dangers of the trip) }\end{array}$ & $\begin{array}{l}\text { Prevenir la escapada de peligros } \\
\text { (*Avoid the trip of dangers) }\end{array}$ \\
\hline $\begin{array}{l}\text { Pulir las imperfecciones de la estatua } \\
\text { (Polish the imperfections on the statue) }\end{array}$ & $\begin{array}{l}\text { Pulir la estatua de imperfecciones } \\
\text { (Polish the statue of imperfections) }\end{array}$ \\
\hline $\begin{array}{l}\text { Pulimentar las manchas del suelo } \\
\text { (Polish the stains from the floor) }\end{array}$ & $\begin{array}{l}\text { Pulimentar el suelo de manchas } \\
\text { (Polish the floor of stains) }\end{array}$ \\
\hline $\begin{array}{l}\text { Purgar los pecados de su alma } \\
\text { (Expiate the sins of his soul) }\end{array}$ & $\begin{array}{l}\text { Purgar su alma de pecados } \\
\text { (Expiate his soul of sins) }\end{array}$ \\
\hline
\end{tabular}




\begin{tabular}{|l|l|}
\hline $\begin{array}{l}\text { Purificar las acciones hechas de su vida } \\
\text { (Purify bad deeds from his life) }\end{array}$ & $\begin{array}{l}\text { Purificar de su vida las acciones hechas } \\
\text { (Purify his life of bad deeds) }\end{array}$ \\
\hline $\begin{array}{l}\text { Rascar las imperfecciones de la pared } \\
\text { (Scrape the imperfections from the wall) }\end{array}$ & $\begin{array}{l}\text { Rascar la pared de imperfecciones } \\
\text { (Scrape the wall of imperfections) }\end{array}$ \\
\hline $\begin{array}{l}\text { Rasurar los pelos de la coronilla } \\
\text { (Shave the hair from one's crown) }\end{array}$ & $\begin{array}{l}\text { Rasurar la coronilla de pelos } \\
\text { (Shave one's crown of hair) }\end{array}$ \\
\hline $\begin{array}{l}\text { Salvar los obstáculos de su carrera } \\
\text { (Overcome the obstacles in one's course) }\end{array}$ & $\begin{array}{l}\text { Salvar su carrera de obstáculos } \\
\text { (*Overcome one's course of obstacles) }\end{array}$ \\
\hline $\begin{array}{l}\text { Separar la estantería del mueble } \\
\text { (Separate the shelves from the furniture) }\end{array}$ & $\begin{array}{l}\text { Separar el mueble de la estantería } \\
\text { (Separate the furniture from the shelves) }\end{array}$ \\
\hline $\begin{array}{l}\text { Soplar la caspa de la chaqueta } \\
\text { (Blow dandruff from one's jacket) }\end{array}$ & $\begin{array}{l}\text { Soplar la chaqueta de caspa } \\
\text { (*Blow one's jacket of dandruff) }\end{array}$ \\
\hline $\begin{array}{l}\text { Sorber el chocolate de los dedos } \\
\text { (Suck chocolate from one's fingers) }\end{array}$ & $\begin{array}{l}\text { Sorber los dedos de chocolate } \\
\text { (*Suck one's fingers of chocolate) }\end{array}$ \\
\hline $\begin{array}{l}\text { Tachar los posibles votantes de la lista } \\
\text { (Cross out possible voters from the list) }\end{array}$ & $\begin{array}{l}\text { Tachar la lista de posibles votantes } \\
\text { (Cross out the list of possible voters) }\end{array}$ \\
\hline $\begin{array}{l}\text { Vaciar el agua del estanque } \\
\text { (Empty the water from the pond) }\end{array}$ & $\begin{array}{l}\text { Vaciar el estanque de agua } \\
\text { (Empty the pond of water) }\end{array}$ \\
\hline
\end{tabular}

All of these constructions also allow a certain secondary locative-possessive predication, but not as a result of the verb's action, but rather prior to it:

Absolver los pecados de su alma (absolve the sins from his soul).

Absolver su alma de pecados (absolve his soul of sins).

*Los pecados están en el alma (*the sins are in the soul) > el alma tiene pecados (the soul has sins).

What the action described by the verb does is break that possession-location relation.

We must specify that in the first alternating construction, the de (of /from) complement does not represent a possession-location relation, but a where from relation, so it must be considered as a different argument from the direct object, never as one of its compliments, in order to alternate in the second construction. Furthermore, some of these constructions are able to alternate the location of the locative where from complement with a generic locative complement. This occurs especially in Spanish in cases where there could be doubt about the independence of the arguments, as it is easy to interpret the de (of/from) complement as a noun complement (thus expressing a possession-location relation) with respects to the direct object: absolver delen su alma los pecados (absolve the sins of/in his soul).

The second alternating construction, where the direct object is the container (absolver su alma de pecados - absolve his soul of sins-), and not the content as in the previous construction (absolver los pecados de su alma -absolve the sins from his soul-), generally also allows alternation with prepositions de (of) and con (with). However, the meaning is very different, both syntactically and semantically. If the complement begins with de (of), which is the true alternating construction, it implies an element that was possessed by the 
container but that no longer is because the element is no longer there: absolver su alma de pecados (absolve his soul of sins). It then becomes the object of the removing action expressed by the verb with respect to the container represented by the direct object. However, if it is a con (with) construction, it does not express the object of the removing action, but becomes a complement of the direct object and depends on it. In this case, it does indicate a possession-location relation with the direct object container:

Absolver su alma de pecados (Absolve his soul of sins):

1. Locative action involving a break in the possession between the object, pecados (sins), and the container, alma (soul).

2. The action is indicated by the verb: absolver (absolve).

Absolver su alma con pecados (*Absolve his soul with sins):

1. Non-locative action, depending on the verb's value, caused upon a direct object (alma -soul-) that has or possesses something (pecados - sins-).

2. The dependence of the noun complement is proved through syntactical mobility:

Absolver con pecados su alma (*absolve with sins his soul) - absolver su alma con pecados (*absolve his soul with sins) vs. absolver de pecados su alma (absolve of sins his soul) - absolver su alma de pecados (absolve his soul of sins).

In order for a removal verb to alternate it must have a manner component in its meaning which includes the possibility of having a given result as well. Thus, the differentiation proposed by Levin and Rappaport between manner and result verbs is, in this case, irrelevant, since either of the two configure the verb as a manner removal verb as apposed to verbs that merely indicate ablative location. In Spanish, both manner and result behave identically when it comes to removal constructions, which makes us unite them under the manner umbrella.

One aspect worthy of mention is that the article tends to disappear in one of the alternating constructions, more specifically, in the one where the content element is introduced by de (of): absolvió los pecados de su alma (he absolved the sins from his soul) / absolvió su alma de pecados (he absolved his soul of sins). Clearly, there could be an article (absolvió su alma de los pecados cometidos en su juventud -he absolved his soul of the sins committed in his youth-), but that normally requires further specification.

According to Talmy (1985), the basic motion event schema consists of figure, ground, path and motion. Along with these internal components, the event can also include manner or cause. Incorporating the manner feature with the verb, through conflation, is one of the possibilities this conceptual element has of being represented syntactically. It can also be represented linguistically as a satellite or in a separate lexical element such as a gerund:

Barrio las migajas del suelo (he swept the crumbs from the floor).

Quito las migajas del suelo barriéndolas (he removed the crumbs from the floor by sweeping them).

As has already been stated by Cifuentes (1999), it is possible to differentiate motion verbs from manner of motion verbs quite precisely 12 . This is a generalization which, if applied to removal verbs, can be objectified by the following features: 
a. Motion verbs are inherently telic, while manner of motion verbs are atelic and are therefore activity verbs. However, both are able to develop marked uses where they behave differently.

Vació el agua del tanque durante dos minutos (He emptied the water from the tank for two minutes)

Vació el agua del tanque en dos minutos (He emptied the water from the tank in two minutes)

Quitó las señales del suelo en dos minutos (He removed the signs from the ground in two minutes)

?Quitó las marcas del suelo durante dos minutos (? He removed the signs from the ground for two minutes)

Manner verbs can show both telic and atelic interpretations, while motion verbs are purely telic. For example, in the case of quitó las marcas del suelo durante dos minotos (he removed the signs from the ground for two minutes), rather than it being interpreted in a sense of duration of activity, it can be interpreted in the sense that two minutes was the length of time the signs remained removed from the ground, but that they may later have been replaced. This interpretation is not possible with manner verbs, where the atelic interpretation clearly refers to carrying out the action. It is true that, especially when combined with other complements, motion verbs could also allow an atelic interpretation which indicates a certain progressive state: Quitó las marcas del suelo durante dos minutos, se puso a fumar, y ya no volvió a hacerlo más the removed the signs from the ground for two minutes, stopped for a smoke, and did not carry on), but in Spanish this would seem more natural if it involved a gerund, estuvo quitando (he was removing), rather than with a simple verb form.

b. Motion verbs always imply location, whether it is a final destination, a starting point or a path, otherwise they are grammatically incorrect. Manner of motion verbs, on the other hand, can be expressed without this spatial component, and therefore can express manner of action content exclusively:

Limpió las estanterias muy mal (he cleaned the shelves badly)

?Quitó los libros muy mal (?he removed the books badly)

It is impossible to conceive quitar mal los libros (removing the books badly) if there is nowhere to remove them from.

c. Manner of motion verbs, because they can be expressed without a directional or spatial component, are able to specify the action's location or situation. Motion verbs, however, cannot and are merely able to express general context for the action.

En su casa, Juan nunca limpia en la cocina (at home, Juan never cleans in the kitchen). *En su casa, Juan siempre quita todo en las fiestas... (*at home, Juan always removes everything at parties...)

d. Manner of motion verbs can be used as a gerund in combination with a motion verb in order to indicate the manner of motion. This use is not possible with motion verbs. 
Juan quito el polvo aspirándolo (Juan disposed of the dust by vacuuming it)

*Juan quitó el polvo retirándolo ("Juan disposed of the dust by removing it)

e. Manner of motion verbs can be combined with structures that imply measuring the motion involved, both for the locatum element and for the location element. Motion verbs, on the other hand, only seem to allow the locatum element to be measured, not location:

Cepillo todas las migajas de la mesa (he brushed all the crumbs from the table). Cepilló casi toda la mesa (he brushed nearly the whole table).

Retiró todas las migajas de la mesa (he removed all the crumbs from the table).

Retiró casi toda la mesa (he removed nearly the whole table).

Clearly this last example is correct, but in it the table is no longer the location element and can only be considered locatum, which does not occur in the manner verb examples because they imply some sort of figure. Other examples can further back these proposals if necessary.

Vacio toda el agua de la botella (he emptied all the water from the bottle).

Vacio toda la botella (he emptied the whole bottle).

Quitó toda el agua de la botella (he removed all the water from the bottle).

* Quitó casi toda la botella (*he removed nearly the whole bottle).

In the vaciar (empty) examples, the direct object could be either the locatum or the location element, but with quitar (remove), it is not possible to consider the location as a direct object. This seems to be so because in vaciar toda la botella (empty the whole bottle) the locatum element is still present, which is not the case with verbs that do not express manner.

It seems quite easy to define vaciar (empty) as a result verb and cepillar (brush) as a manner verb, and I am not saying this distinction cannot be made, but what I would like to stress is that as removal verbs, their behaviour is syntactically identical whether they are manner verbs or result verbs. Thus, I would like to conclude that the distinction is not syntactically relevant in Spanish and that they can, therefore, be considered to be equivalent.

\subsection{Nutrition verbs}

There is a group of verbs that are neither ablative nor removal verbs but can take certain alternations due to the similarity between them. I am talking about nutrition verbs in optional locative constructions in this case, and where a relation between content-locatum and container-location can be established. I believe there is a semantic similarity in the examples proposed, in spite of the syntactical difference, in that these verbs involving food and drink imply the removal of an element, the locatum, through the physical process of feeding. Evidently I am not suggesting that these verbs always allow alternations, as that would be impossible partly because they are not three-argument verbs. What I am suggesting is that when it is pragmatically possible to localize the theme argument, alternation is also possible. 


\begin{tabular}{|l|l|}
\hline $\begin{array}{l}\text { Se bebió la cerveza en/de la jarra } \\
\text { (He drank the beer in/from the jug) }\end{array}$ & $\begin{array}{l}\text { Se bebió la jarra con la cerveza } \\
\text { (He drank the jug with beer (in it)) }\end{array}$ \\
\hline $\begin{array}{l}\text { Se comió un chorizo entre el pan } \\
\text { (He ate a sausage in bread) }\end{array}$ & $\begin{array}{l}\text { Se comió el pan con un chorizo (dentro) } \\
\text { (He ate his bread with a sausage (in it)) }\end{array}$ \\
\hline $\begin{array}{l}\text { Degustó el vino en/de la botella } \\
\text { (He tasted the wine in/from the bottle) }\end{array}$ & $\begin{array}{l}\text { Degustó la botella con el vino } \\
\text { (He tasted the bottle with the wine (in it)) }\end{array}$ \\
\hline $\begin{array}{l}\text { Devoró un chorizo entre el pan } \\
\text { (He devoured a sausage in bread) }\end{array}$ & $\begin{array}{l}\text { Devoró el pan con un chorizo (dentro) } \\
\text { (He devoured his bread with a sausage (in it)) }\end{array}$ \\
\hline $\begin{array}{l}\text { Se tragó un chorizo entre el pan } \\
\text { (He swallowed a sausage in bread) }\end{array}$ & $\begin{array}{l}\text { Se tragó el pan con un chorizo (dentro) } \\
\text { (He swallowed the bread with a sausage (in it)) }\end{array}$ \\
\hline
\end{tabular}

\section{References}

Anderson, S. R. (1971): "On the role of deep structure in semantic interpretation", Foundations of Language, 7, pp. 387-396.

Beavers, J. T. (2006): Argument/oblique alternations and the structure of lexical meaning, Doctoral Dissertation, University of Stanford.

Cifuentes Honrubia, J. L. (1999): Sintaxis y semántica del movimiento. Aspectos de gramática cognitiva. Alicante: Instituto de Cultura 'Juan Gil Albert'.

Cifuentes Honrubia, J. L. (2004): "Verbos locales estativos en español", in J. L. Cifuentes Honrubia y C. Marimón Llorca (eds.): Estudios de lingüistica: el verbo, Alicante: University of Alicante, pp. 73-118.

Cifuentes Honrubia, J. L. (2005): "Sobre verbos locatum y de localización", in L. Santos Río - J. Borrego - J. F. García Santos - J. J. García Asencio - E. Prieto de los Mozos (eds.): Palabras, norma y discurso. En memoria de Fernando Lázaro Carreter, Salamanca: University of Salamanca, pp. 333-346.

Cifuentes Honrubia, J. L. (2006a): "Verbos denominales locales en español", in E. de Miguel - A. Palacios \& A. Serradilla (eds.): Estructuras léxicas y estructura del léxico, Frankfurt: Peter Lang, pp. 247-271.

Cifuentes Honrubia, J. L. (2006b): “Alternancias verbales en español”, Revista Portuguesa de Humanidades, 10-1/2, 2006, pp. 107-132.

Cifuentes Honrubia, J. L. (2009): “Tipología de las alternancias locales en español”. In B. Brzozowska-Zburzynska (ed.): Encuentros de lingüistica general y aplicada, Lublin: Universidad Marii Curie-Skłodowskiej, (in press).

Di Tullio, A. L. (2002): "Los difusos límites de la 'alternancia locativa' en español”, en A. Veiga y M. R. Pérez (eds.): Lengua española y estructuras gramaticales, University of Santiago de Compostela: Santiago de Compostela, pp. 131-140.

Iwata, S. (2005a): "Locative alternation and two levels of verb meaning", Cognitive Linguistics, 16-2, pp. $355-407$.

Iwata, S. (2005b): "The role of verb meaning in locative alternations", in H.C. Boas y M. Fried (eds.): Construction Grammar: Back to the Roots, Amsterdam/Philadelphia: John Benjamins, pp. $101-136$.

Iwata, S. (2008): Locative Alternation. A Lexical-Constructional Approach, Amsterdam: John Benjamins.

Laffut, A. (2006): Three-Participant Constructions in English: A Functional-Cognitive Approach to Caused Relations, Amsterdam: John Benjamins.

Levin, B. (1993), English verb classes and alternations. A preliminary investigation. Chicago: University of Chicago Press. 
Levin, B. (2003): "Objecthood and Object Alternations", Department of Linguistics, UCLA, Los Angeles, CA, (http://www.stanford.edu/ bclevin/ucla03alt.pdf).

Levin, B. (2006): "Lexical Semantics and Argument Realization II. Structuring Event Structure", DGfS/GLOW Summer School, Stuttgart, (http://www.stanford.edu/ bclevin/dgfs06evstr.pdf).

Levin, B. y Rappaport Hovav, M. (2005): Argument Realization, Cambridge: Cambridge University Press.

Levin, B. y Rappaport Hovav, M. (2008): "Lexical Conceptual Structure", in K. von Heusinger, C. Maienborn, \& P. Portner (eds.): Semantics: An International Handbook of Natural Language Meaning, Mouton de Gruyter, Berlin (in press).

Moreno Cabrera, J. C. (1998): "Las alternancias locativas desde el punto de vista de la semántica de esquemas eventivos", in M. D. Núñez (ed.): IV Jornadas de Lingüística, Cádiz: University of Cádiz, pp. 143-172.

Moreno Cabrera, J. C. (2003): Semántica y gramática. Sucesos, papeles semánticos y relaciones sintácticas, Madrid: A. Machado Libros.

Pinker, S. (1989): Learnability and Cognition. The Acquisition of Argument Structure, Cambridge: The MIT Press.

Puskejovsky, J. (1991): "The Syntax of Event Structure", Cognition, 41, pp. 47-81.

Rappaport Hovav, M. y Levin, B. (1988): "What to do with $\theta$-roles", in W. Wilkins (ed.): Thematic relations, New York: Academic Press, pp. 7-36.

Rappaport Hovav, M. y Levin, B. (2003): "Root and Template in the Representation of Verb Meaning", Department of Linguistics, Stanford University, Stanford, CA, (http://www.stanford. edu/ bclevin/su03.pdf).

Rappaport Hovav, M. y Levin, B. (2008) "Reflections on Manner/Result Complementarity", in E. Doron, M. Rappaport Hovav, \& I. Sichel (eds.): Syntax, Lexical Semantics, and Event Structure, Oxford University Press, Oxford, UK (in press).

Talmy, L. (1985): "Lexicalization patterns: semantic structure in lexical forms", in T. Shopen (ed.): Language typology and syntactic descriptions, New York: Cambridge University Press, pp. 57-149. 